\title{
PECULIARITIES OF GROWTH AND DEVELOPMENT OF RICE PLANTS DEPENDING ON BIOLOGICAL PROPERTIES OF VARIETIES AND CULTIVATION CONDITIONS
}

\section{Vozhehova R. A.}

\section{INTRODUCTION}

It is typical for rice, as for other higher plants, to form organs during ontogenesis according to the stages of organogenesis. Instead, not all researchers stick to clear boundaries of the division into organogenesis stages. Considering the fact that rice has no clear boundaries between VIII and IX stages, the crop has 11 stages of organogenesis. Such a distribution of stages of organogenesis in rice is inappropriate because of two reasons. Firstly, the characteristics of organs formation peculiarities in all studies related to the species of higher plants at each stage of the organogenesis has been widely introduced in biological literature, and the corresponding number of the stage of organogenesis is perceived not simply as a sequence number, but as a set of organ formation processes. Due to this fact the change in numbering of the last stages brings some confusion. Secondly, VIII and IX stages of organogenesis in rice are not always indistinct. It is established that at lowering of air temperature during the period of panicleing, flowering starts with a delay of 1-3 days and more, that is development of plants at VIII stage of organogenesis is prolonged ${ }^{1,2,3}$.

Most of the above mentioned researchers did not succeed in learning phenotypal variability of features depending on genotype, as their experiments were performed on the example of one or three varieties. In addition, the potential opportunities for the development of quantitative features of rice, which could reveal the conditionality of these features by genotype, have not been studied at the time. Without such studies, it is almost impossible to clearly formulate the directions of selection, a model of rice varieties of rice regions of Ukraine and develop backgrounds for effective selection of elite plants ${ }^{4,5}$.

\footnotetext{
${ }^{1}$ Ерыгин П. С. Физиология риса. Москва: Колос, 1981. 208 с.

${ }^{2}$ Седловский А. И., Колточник С. Н., Колточник М. М. Формирование количественных признаков у риса. Алма-Ата, 1985. 214 с.

${ }^{3}$ Методика державного сортовипробування сільськогосподарських культур. Київ, 2000. Вип. $1.100 \mathrm{c}$.

${ }^{4}$ Сонде Т. А., Масливец В. А., Баргукова А. Я. Фотосинтетическая деятельность и урожайность сортов риса в зависимости от режима орошения и уровня азотного питания. Устойчивое производство риса: настоящее и перспективы: матер. Межд. науч.-практ. конф., 5-9 сентября 2006 г. Краснодар, 2006. С. 159-165.
} 


\section{Plant height and stem foliaceous dynamics}

The research was conducted at the Institute of Rice of the National Academy of Agrarian Sciences of Ukraine in order to define the peculiarities of the formation of quantitative features during the ontogenesis, which determine the productivity of rice in the South of Ukraine. In the study, we used different by the duration of vegetation period varieties: early ripening Mutant-428, Malysh; middle-ripening Ukraine-96, Myrnyi; late-ripening Krasnodarskyisky-424 and Don-883. To determine the potential opportunities for the development of quantitative characteristics of plants they were cultivated at different density $(2 \times 15,15 \times 15,30 \times 30)$ and various doses of nitrogen fertilizers (ammonium sulfate was applied in the doses $\mathrm{N}_{0}, \mathrm{~N}_{90}, \mathrm{~N}_{180}$ ). Fertilizers were applied in two periods: sowing (70\%) and at the stage of 3-4 leaves of the crop (30\%).

For biometric processing we selected 20 plants on each variant in the field conditions. We measured their height, the leaves dimensions, the length of the main and lateral panicles, the number of internodes in the main and lateral stems, counted the total number of lateral stems of each order, the number of ears and grains in the main and side panicles, the weight of grain from individual panicles and a plant on the whole.

Vegetative features: the length and foliaceous of the stems, tillering of the plants are not direct elements of productivity, but have a significant impact on its formation, since the plant height depends on the resistance to lodging, and the shape, size and location of leaves determines the level of physiological processes that are associated with yield ${ }^{6}$.

Plant height varies significantly depending on the place of cultivation, sowing norms and plant density, doses of nitrogen fertilizers, air temperature and other factors. It is established that the increase in the duration of the day, doses of nitrogen fertilizers, flooding depth predetermine the intense growth of rice plants, and low air temperatures inhibit plant growth ${ }^{7}$.

According to Ukrainian researchers ${ }^{8,9,10,11}$ modern rice varieties differ significantly in the height of plants, which depends primarily on their genetic

${ }^{5}$ Ванцовський А. А., Вожегов С. Г., Вожегова Р. А. Агроекологічні аспекти вирощування рису. Таврійський науковий вісник: зб. наук.пр. Херсон: Айлант, 2004. Вип. 32. С. 220-224.

${ }^{6}$ Орлюк А. П., Вожегова Р. А., Федорчук М. І. Селекція і насінництво рису. Херсон: Айлант, 2004. $250 \mathrm{c}$.

${ }^{7}$ Вожегова Р. А. Теоретичні основи і результати селекції рису в Україні: монографія. Херсон, 2010. 345 c.

${ }^{8}$ Вожегова Р. А., Шпак Д. В., Петкевич 3. 3. Влияние погодных условий на реализацию потенциала продуктивности образцов национальной коллекции риса различных групп спелости. Материалы международной конференции. Скадовськ, 2008. С. 152-155.

${ }^{9}$ Кольцов А. В. Технология возделывания риса в Крыму. Симферополь, 1991. 415 с.

10 Петкевич 3. З., Шпак Т. Н., Вожегова Р. А. Влияние температурних условий на урожайность риса сортов разных групп спелости. Наукові праці Південного філіалу 
characteristics, technology of cultivation and weather conditions. Among nongenetic factors, a large influence on the development of features has a plant nutrition area and the level of nitric supply.

Regarding the effect of the area of nutrition on the plant height there are different conclusions in the scientific literature. In particular, D. H. Mame$\operatorname{dov}^{12}$, N. P. Volkova ${ }^{13}$ note that under the thickening of crops the height of plants decreases, but at the same time, I. B. Byzhanov ${ }^{14}$ believe that the height of plants, on the contrary, increases with increasing in their number per $1 \mathrm{~m}^{2}$. Such ambiguous and even opposite conclusions in the researches could be explained by the fact that the works were performed in different geographical points and with different varieties, which react differently on agroecological factors.

Rice plants at the early stages of organogenesis, until V-VI stages, grow very slowly, but at the stage of intensive growth and panicleing (VII-VIII stages of organogenesis) the stem growth is increasing rapidly, as a result, panicle is quickly imposed from the sinuses of the leaf. Further growth is slow. Our research has shown that the decrease in plant density affected differently on the growth intensity of the main stem of rice plants (Table 1): at the early ripening and middle-ripening varieties increase the nutrition area of plants that led to more intensive growth. As you can see, the largest plant height is observed by the nutrition area $30 \times 30 \mathrm{~cm}$, less - in the variant $15 \times 15 \mathrm{~cm}$, and the smallest - in the variant $2 \times 15 \mathrm{~cm}$.

Another reaction on the increase of plant nutrition area was in lateripening varieties Krasnodarskyi-424 and Don-883. Their largest plant height is defined at the smallest nutrition area $-2 \times 15 \mathrm{~cm}$, and as the nutrition area increases, the height of the plants decreased.

By the nature of the stem growth, the studied rice varieties differed somewhat. After analyzing the experimental data, it could be seen that at the early ripemimg variety Malysh growth of a stem after a massive flowering regardless on plant nutrition area almost stopped, and in other varieties,

«Кримський агротехнологічний університет» Національного аграрного ун-ту. Сімферополь, 2007. Вип. 100: Сільськогосподарські науки. С. 186-191.

${ }^{11}$ Дуденко В. П., Байгулов П. Г., Устьянцева Р. Н. Удобрение риса на незасоленных такыровидных сероземах Акдалинского мас сива. Биология и минеральное питание риса. Алма-Ата, 1976. С. 184-200.

12 Мамедов Д. Х. Густота стояния как фактор повышения урожая риса при культуре пересадкой в Азербайджанской СССР: автореф. дис. ... канд. с.-х. наук. Баку, 1964. 23 с.

${ }_{13}^{13}$ Волкова Н. П. К вопросу изучения агробиологических особенностей перспективных сортов риса. Материаль Всес. коорд.-метод. совещания по селекиии, семеноводству и качеству риса, проектирования и эксплуатации рисовых оросительных систем. Краснодар, 1972. C. 37-39.

${ }^{14}$ Бижанов И. Б. Сроки, способы и нормы высева риса в Талды-Курганской области: автореф. дис. ... канд. с.-х. наук. Алма-Ата, 1972. 23 с. 
including early-ripening Mutant-428, although it slowed down after massive flowering, it continued to the end of the vegetation.

Table 1

The dynamics of plant height in rice varieties at different nutrition areas, $\mathbf{m m}$

\begin{tabular}{|c|c|c|c|c|c|c|c|c|}
\hline \multirow{2}{*}{ Variety } & \multirow{2}{*}{$\begin{array}{l}\text { Nutrition } \\
\text { area, cm }\end{array}$} & \multicolumn{7}{|c|}{ Number of days after sprouting } \\
\hline & & 15 & 25 & 35 & 55 & 65 & 75 & 95 \\
\hline \multirow{3}{*}{ Mutant-428 } & $2 \times 15$ & 2 & 2 & 4 & 492 & 562 & 570 & 653 \\
\hline & $15 \times 15$ & 2 & 2 & 4 & 615 & 648 & 690 & 750 \\
\hline & $30 \times 30$ & 2 & 2 & 4 & 530 & 585 & 695 & 785 \\
\hline \multirow{3}{*}{ Malysh } & $2 \times 15$ & 2 & 2 & 4 & 480 & 505 & 635 & 645 \\
\hline & $15 \times 15$ & 2 & 2 & 4 & 585 & 615 & 695 & 705 \\
\hline & $30 \times 30$ & 2 & 2 & 4 & 520 & 570 & 690 & 715 \\
\hline \multirow{3}{*}{ Ukraine-96 } & $2 \times 15$ & 2 & 2 & 4 & 615 & 665 & 745 & 903 \\
\hline & $15 \times 15$ & 2 & 2 & 4 & 670 & 710 & 810 & 1051 \\
\hline & $30 \times 30$ & 2 & 2 & 4 & 685 & 720 & 815 & 1223 \\
\hline \multirow{3}{*}{ Myrnyi } & $2 \times 15$ & 2 & 2 & 4 & 605 & 650 & 740 & 895 \\
\hline & $15 \times 15$ & 2 & 2 & 4 & 680 & 695 & 753 & 915 \\
\hline & $30 \times 30$ & 2 & 2 & 4 & 715 & 725 & 790 & 925 \\
\hline \multirow{3}{*}{$\begin{array}{c}\text { Krasnodarskyi- } \\
424\end{array}$} & $2 \times 15$ & 2 & 2 & 4 & 325 & 612 & 840 & 945 \\
\hline & $15 \times 15$ & 2 & 2 & 5 & 452 & 548 & 815 & 920 \\
\hline & $30 \times 30$ & 2 & 2 & 4 & 330 & 510 & 810 & 900 \\
\hline \multirow{3}{*}{ Don-883 } & $2 \times 15$ & 2 & 2 & 4 & 330 & 615 & 842 & 950 \\
\hline & $15 \times 15$ & 2 & 2 & 5 & 448 & 550 & 805 & 942 \\
\hline & $30 \times 30$ & 5 & 5 & 4 & 332 & 512 & 800 & 938 \\
\hline \multirow{3}{*}{$\mathrm{LSD}_{05}$} & $2 \times 15$ & & & & 13 & 12 & 19 & 20 \\
\hline & $15 \times 15$ & & & & 15 & 14 & 21 & 22 \\
\hline & $30 \times 30$ & & & & 15 & 14 & 23 & 22 \\
\hline
\end{tabular}

There is a close connection between the height of the plant and the length of the individual internodes changes (Table. 2). In all the studied varieties of rice, starting from the VI stage of organogenesis, the first one, counting from panicle, inter-node, which is characterized with the most intensive growth at VII stage of organogenesis. This internode at the end of the vegetation period has the largest value.

It is established that most varieties of rice develop only 4-6 internodes, with only the first 3-4, counting from the panicles, have a relatively large length, they can be assessed visually or using special equipment.

The next 2-3 internodes are elongated only for a few millimeters, and the remaining internodes in the rice are very close to each other. 
Table 2

Length of internodes $(\mathrm{mm})$ in rice varieties at different plant nutrition areas

\begin{tabular}{|c|c|c|c|c|}
\hline \multirow{2}{*}{ Variety } & Nutrition & \multicolumn{3}{|c|}{ Number of internodes counting from panicle } \\
\cline { 2 - 5 } & area, cm & $\mathbf{1}$ & $\mathbf{2}$ & $\mathbf{3}$ \\
\hline \multirow{3}{*}{ Mutant-428 } & $2 \times 15$ & 351 & 203 & 99 \\
\cline { 2 - 5 } & $15 \times 15$ & 424 & 225 & 101 \\
\cline { 2 - 5 } & $30 \times 30$ & 440 & 230 & 114 \\
\hline \multirow{3}{*}{ Malysh } & $2 \times 15$ & 346 & 208 & 91 \\
\cline { 2 - 5 } & $15 \times 15$ & 380 & 234 & 96 \\
\cline { 2 - 5 } & $30 \times 30$ & 385 & 236 & 93 \\
\hline \multirow{3}{*}{ Ukraine-96 } & $2 \times 15$ & 469 & 315 & 96 \\
\cline { 2 - 5 } & $15 \times 15$ & 485 & 334 & 97 \\
\cline { 2 - 5 } & $30 \times 30$ & 494 & 342 & 97 \\
\hline \multirow{3}{*}{ Krasnodarskyi-424 } & $2 \times 15$ & 472 & 320 & 103 \\
\cline { 2 - 5 } & $15 \times 15$ & 483 & 326 & 104 \\
\cline { 2 - 5 } & $30 \times 30$ & 498 & 328 & 104 \\
\cline { 2 - 5 } & $2 \times 15$ & 481 & 350 & 114 \\
\hline \multirow{3}{*}{ Don-883 } & $15 \times 15$ & 478 & 328 & 112 \\
\hline & $2 \times 30$ & 461 & 329 & 110 \\
\cline { 2 - 5 } & $15 \times 15$ & 479 & 349 & 122 \\
\cline { 2 - 5 } & $30 \times 30$ & 474 & 345 & 120 \\
\hline \multirow{3}{*}{ LSD 05} & $2 \times 15$ & 11 & 343 & 119 \\
\cline { 2 - 5 } & $15 \times 15$ & 10 & 9 & 5 \\
\cline { 2 - 5 } & $30 \times 30$ & 13 & 10 & 5 \\
\hline
\end{tabular}

At different nutrition areas, the change in the length of individual internodes is similar to the changes in the overall length of the stem in different varieties. The first, starting from the panicle, internode occupies 51$56 \%$ of the total length of the stem. As it is evident from the Table 3, the largest changes were observed in the first and second internodes of early- and middle-ripening varieties: as the plant nutrition area increases, the indicators of these morphostructural elements increased either. The length of the third internodes, starting from the panicle, was stable.

As in other varieties, late-ripe genotypes (Krasnodarskyi-424 and Don883) had the largest internodes located first starting from the panicle, but their change in different supply areas was slightly different in comparison to more fast-ripening varieties. It turned out that with the increase in the nutrition area the length of internodes in the late varieties decreases. The same regularity was observed in other internodes. 
The number of leaves on the plant serves as a varietal feature and fluctuates in the different by vegetation period duration varieties within 10-13. The speed and duration of the formation of leaves depends essentially on theenvironmental conditions.

The foliaceousness is increased by 1-3 leaves under the increasing doses of nitrogen fertilizers, plant nutrition area, and also under the influence of other factors. It is established that in the period of panicleing varietal differences in the number of green leaves disappear or are unclear. There are on average 4 , and on a rich agrobackground -5 green leaves per the stem. The most significant impact on the yield formation has the length and width of the leaves ${ }^{15}$.

Dark color of leaves is regarded as an indicator of increased content of chlorophyll. It is assumed that the dark green leaves are more productive in photosynthesis and more intensively accumulate dry matter. Instead, in practice, the forms with wide light-green large leaves appear to be quite productive and not inferior to the yield of dark-coloured ${ }^{16}$. Obviously, in order to use the coloring of the leaf as an indicator (marker) of productivity of plants, it is necessary to possess information about the connection between chlorophyll and yield. But at present there are no works which would reveal the photosynthetic activity of different types of rice plants according to the structure of bush, color of leaves, degree of thickening, etc.

The duration of leaves life and the intensity of utilization of organic matter from vegetative organs to generative have some positive effect on the yield of variety. By the beginning of ripening of rice seeds, in the plants of medium-and late-ripening varieties there remain viable 3-4 upper leaves, and 2-3 ones in early-ripening varieties. The remaining 6-8 leaves die. The dying out is in different forms at different ages both of the leaves themselves and the plants on the whole and depends on the biological characteristics of the samples and the vegetation conditions. Thus, early sowing, elevated doses of nitrogen fertilizers lead to an increase in life-time of leaves ${ }^{17}$. The later leaves die out, the greater is the period they can perform photosynthesis and the more their lives will affect on the productive processes.

Unlike many cereal crops, leaves and straw of rice before the full ripening of grain contains $60-70 \%$ of water, they are still viable and contain a significant amount (0.8-1.0 t/ha) of reserved matter that is practically unused. Application of Potassium fertilizers can strengthen the outflow of the

\footnotetext{
15 Зглинская Н. Л., Иванова А. В. Влияние калия на урожай риса в условиях различного содержания усвояемых форм его в почвах. Бюл. НТИ ВНИИ риса. Краснодар, 1972. Вып. VIII. C. 71-75.

${ }^{16}$ Волкова Н. П., Сметанин А. П. Листообразование у некоторых сортов риса. Бюл. НТИ ВНИИ риса. Краснодар, 1973. Вып. IX. С. 10-14.

${ }^{17}$ Дорошенко Т. Н., Петибская В. С. Особенности фотосинтеза и дыхания сортов риса интенсивного типа. Бюл. НТИ ВНИИ риса. 1980. Вып. 28. С. 38-42.
} 
substances from the lower leaves to the upper ones ${ }^{18}$, but such artificial measures lead only to a partial increase in the attraction of the substance by kernels, resulting in a slightly increased kernel size, but they do not cause a significant increase in the yield.

Thus, the extension of the life of leaves and stems increases the absorption capacity of panicle on the whole and of kernels, in particular, remains an important and relevant question of rice breeding for productivity. The end of functing of the upper leaves should occur simultaneously with grain ripening. This synchronization in the development of rice plants is quite real, because among the collection samples there are forms in which the dying out of all leaves takes place simultaneously with the ripening of grain.

It was established that in the early ripening varieties (Mutant-428, Malysh) at the final stage (II stage of organogenesis) ther is formed, basically, 9-10, only in some years - 11 leaves; in the middle ripening ones (Ukraine-96, Myrnyi) - 11-12, rarely 13 leaves; in the late ripening ones (Krasnodarskyi424, Don-883) - 12-13 leaves (Table 3). The number of leaves in the same varieties in different years varied insignificantly, it was manifested in different periods of ontogenesis. The slightest differences were manifested on 2-3 day from the beginning of sprouting, then they were slightly increased, but certain patterns in this increase were not found.

Increasing the area of plant nutrition leads to some increase in the number of leaves, but again it was insignificant, by 1-2 leaves (Table 4).

The largest number of leaves was formed in the different area of plants nutrition in the late-ripening varieties; it is somewhat less in middle-ripening and the least - in the early-ripening genotypes.

With more intense mineral nutrition, rice plants' productivity increased. Our research has shown that the dynamics of the formation of leaves depends on the group of ripeness of rice varieties (Table 5). In early and middleripening varieties increase in the dose of nitrogen did not lead to changes in the number of leaves in different periods of the plants' ontogenesis. Instead the late varieties (Krasnodarskyi-424 and Don-883) significantly increased the number of leaves at the application of nitrogen fertilizers. This increase was particularly noticeable in the variant of $\mathrm{N}_{180}$.

Thus, late-ripening varieties form not only more leaves per plant, but also have stronge reaction on the increase of nitrogen fertilization by this parameter.

The photosynthetic potential of the plants determines and provides one or another level of productivity, it depends on the size of the leaf surface, other factors and the duration of their life.

18 Алешин Е. П., Сметанин А. П. Минеральное питание риса. Краснодар: Краснодарское книжное издательство, 1965.95 с. 
Table 3

Dynamics of setting of leaves at different varieties of rice

\begin{tabular}{|c|c|c|c|c|c|}
\hline \multirow{2}{*}{ Varieties } & \multirow{2}{*}{ Year } & \multicolumn{4}{|c|}{ Number of days after sprouting } \\
\cline { 2 - 6 } & & $\mathbf{2 - 3}$ & $\mathbf{1 4 - 1 5}$ & $\mathbf{2 3 - 2 5}$ & $\mathbf{3 7 - 3 8}$ \\
\hline \multirow{3}{*}{ Mutant-428 } & 2003 & 5.0 & 7.8 & 9.7 & 10.5 \\
\cline { 2 - 6 } & 2004 & 5.5 & 8.4 & 10.3 & 11.0 \\
\cline { 2 - 6 } & 2005 & 5.6 & 8.1 & 10.1 & 10.6 \\
\hline \multirow{3}{*}{ Malysh } & 2003 & 5.1 & 7.6 & 8.5 & 9.3 \\
\cline { 2 - 6 } & 2004 & 5.6 & 8.2 & 8.8 & 9.7 \\
\cline { 2 - 6 } & 2005 & 5.7 & 7.9 & 8.7 & 9.1 \\
\hline \multirow{3}{*}{ Ukraine-96 } & 2003 & 5.1 & 7.5 & 9.4 & 11.1 \\
\cline { 2 - 6 } & 2004 & 5.4 & 7.8 & 9.6 & 11.7 \\
\cline { 2 - 6 } & 2005 & 5.7 & 8.0 & 10.3 & 12.0 \\
\hline \multirow{3}{*}{ Myrnyi } & 2003 & 5.8 & 8.1 & 10.9 & 11.4 \\
\cline { 2 - 6 } & 2004 & 6.0 & 8.3 & 10.9 & 12.0 \\
\cline { 2 - 6 } & 2005 & 5.8 & 7.9 & 10.5 & 12.3 \\
\hline \multirow{3}{*}{ Krasnodarskyi-424 } & 2003 & 5.3 & 8.4 & 10.6 & 12.9 \\
\cline { 2 - 6 } & 2004 & 5.0 & 8.8 & 10.4 & 12.6 \\
\cline { 2 - 6 } & 2005 & 5.7 & 8.7 & 11.1 & 12.4 \\
\hline \multirow{3}{*}{ Don-883 } & 2003 & 5.0 & 7.8 & 10.9 & 13.0 \\
\cline { 2 - 6 } & 2004 & 5.6 & 8.7 & 10.1 & 13.1 \\
\cline { 2 - 6 } & 2005 & 6.0 & 8.4 & 10.8 & 12.7 \\
\hline \multirow{3}{*}{ LSD 05} & 2003 & 0.01 & 0.15 & 0.27 & 0.27 \\
\cline { 2 - 6 } & 2004 & 0.05 & 0.16 & 0.31 & 0.28 \\
\cline { 2 - 6 } & 2005 & 0.04 & 0.15 & 0.24 & 0.25 \\
\hline & & & & & \\
\hline
\end{tabular}

Table 4

The number of leaves in different varieties of rice, depending on the nutrition area, pcs.

\begin{tabular}{|c|c|c|c|}
\hline \multirow{2}{*}{ Variety } & \multicolumn{3}{|c|}{ Plant nutrition area } \\
\cline { 2 - 4 } & $\mathbf{2 \times \mathbf { 1 5 }}$ & $\mathbf{1 5} \times \mathbf{1 5}$ & $\mathbf{3 0 \times 3 0}$ \\
\hline Mutant-428 & $10.3 \pm 0.22$ & $10.7 \pm 0.21$ & $11.0 \pm 0.20$ \\
\hline Malysh & $9.7 \pm 0.21$ & $10.2 \pm 0.21$ & $10.5 \pm 0.21$ \\
\hline Ukraine-96 & $11.8 \pm 0.20$ & $12.0 \pm 0.20$ & $12.1 \pm 0.19$ \\
\hline Myrnyi & $12.1 \pm 0.23$ & $11.8 \pm 0.22$ & $12.6 \pm 0.19$ \\
\hline Krasnodarskyi-424 & $13.0 \pm 0.19$ & $12.7 \pm 0.21$ & $13.1 \pm 0.21$ \\
\hline Don-883 & $13.1 \pm 0.21$ & $12.6 \pm 0.19$ & $13.0 \pm 0.21$ \\
\hline
\end{tabular}

We have established that rice varieties in Ukraine also differ in the area of leaf surface of plants (Table 6). These differences are more clearly manifested between early- and late-ripening varieties; middle-ripening 
varieties (Ukraine-96, Myrnyi) do not differ from the early-ripening varieties Mutant-428 and Malysh, and the variety Ukraine-96 has a much larger leaf surface than other mentioned varieties of early- and middleripening group.

Table 5

Dynamics of setting of leaves on the main stem of rice at different doses of nitrogen fertilizers and nutrition area $30 \times 30 \mathrm{~cm}$, days

\begin{tabular}{|c|c|c|c|c|c|c|}
\hline \multirow{3}{*}{ Variety } & \multirow{2}{*}{$\begin{array}{c}\text { Nitrogen } \\
\text { dose, } \mathbf{~ k g / h a}\end{array}$} & \multicolumn{5}{|c|}{$\begin{array}{c}\text { Number of days after the beginning } \\
\text { of sprouting }\end{array}$} \\
\cline { 2 - 7 } & & $\mathbf{2}$ & $\mathbf{9}$ & $\mathbf{1 6}$ & $\mathbf{2 3}$ & $\mathbf{4 0}$ \\
\hline \multirow{3}{*}{ Mutant-428 } & 0 & 5.1 & 6.4 & 7.5 & 9.6 & 10.1 \\
\cline { 2 - 7 } & 90 & 5.5 & 6.1 & 8.0 & 10.2 & 10.6 \\
\cline { 2 - 7 } & 180 & 5.0 & 6.6 & 7.6 & 10.0 & 10.7 \\
\hline \multirow{3}{*}{ Malysh } & 0 & 5.0 & 6.3 & 7.4 & 9.2 & 10.3 \\
\cline { 2 - 7 } & 90 & 5.2 & 5.9 & 8.0 & 9.5 & 10.2 \\
\cline { 2 - 7 } & 180 & 5.2 & 6.4 & 7.8 & 9.4 & 10.1 \\
\hline \multirow{3}{*}{ Ukraine-96 } & 0 & 5.3 & 6.1 & 7.6 & 9.3 & 11.5 \\
\cline { 2 - 7 } & 90 & 5.2 & 6.3 & 7.8 & 9.5 & 11.8 \\
\cline { 2 - 7 } & 180 & 5.4 & 5.8 & 8.0 & 9.4 & 11.6 \\
\hline \multirow{3}{*}{ Myrnyi } & 0 & 5.7 & 6.3 & 8.0 & 10.7 & 11.8 \\
\cline { 2 - 7 } & 90 & 5.9 & 6.7 & 8.5 & 11.0 & 12.0 \\
\cline { 2 - 7 } & 180 & 5.8 & 6.6 & 8.7 & 10.9 & 11.9 \\
\hline \multirow{3}{*}{ Krasnodarskyi-424 } & 0 & 5.5 & 7.7 & 8.1 & 10.2 & 11.2 \\
\cline { 2 - 7 } & 90 & 5.8 & 8.3 & 8.8 & 11.0 & 12.0 \\
\cline { 2 - 7 } & 180 & 6.0 & 9.0 & 9.0 & 11.8 & 13.1 \\
\hline \multirow{3}{*}{ Don-883 } & 0 & 5.3 & 7.8 & 8.2 & 10.1 & 11.0 \\
\cline { 2 - 7 } & 90 & 5.6 & 8.2 & 9.0 & 10.9 & 12.2 \\
\cline { 2 - 7 } & 180 & 5.8 & 9.1 & 9.4 & 12.0 & 13.5 \\
\hline \multirow{3}{*}{ LSD $_{05}$} & 0 & 0.06 & 0.11 & 0.18 & 0.22 & 0.18 \\
\cline { 2 - 7 } & 90 & 0.10 & 0.11 & 0.17 & 0.21 & 0.21 \\
\cline { 2 - 7 } & 180 & 0.09 & 0.12 & 0.19 & 0.19 & 0.26 \\
\hline
\end{tabular}

It should be noted, according to the average group characteristics of the ealy- and middle-ripening rice varieties may be distinguished by the area of leaf surface, but within each group there is a differentiation of genotypes by the investigated characteristic. It is obvious that late-ripening varieties form a much larger leaf surface than the genotypes of other groups of ripeness.

Given in the Table 6 data indicate that the increase in the nutrition area, as a rule, leads to an increase in the total area of the leaf surface of plants in the varieties with a different type of growth and development. This process of growth of the total leaf area is pre-conditioned by the corresponding increase in the leaves of different layers, Table 6 presents presents the dynamics of the leaf area of the $1^{\text {st }}$ and $2^{\text {nd }}$ leaves from panicle areas. 
Table 6

Leaf area of rice varieties depending on the plant nutrition area

\begin{tabular}{|c|c|c|c|c|}
\hline \multirow{4}{*}{ Variety } & \multirow{2}{*}{$\begin{array}{c}\text { Nutrition } \\
\text { area, cm }\end{array}$} & $\begin{array}{c}\text { The total area } \\
\text { of the leaf } \\
\text { surface of } \\
\text { plants, cm }\end{array}$ & \multicolumn{2}{|c|}{$\begin{array}{c}\text { The area of } \\
\text { leaves, }\end{array}$} \\
\cline { 3 - 5 } & & $\begin{array}{c}\text { 1st from } \\
\text { panicle }\end{array}$ & $\begin{array}{c}\text { 2nd from } \\
\text { panicle }\end{array}$ \\
\hline \multirow{3}{*}{ Mutant-428 } & $2 \times 15$ & $70.8 \pm 1.2$ & $26.1 \pm 0.6$ & $18.9 \pm 0.4$ \\
\cline { 2 - 5 } & $15 \times 15$ & $75.6 \pm 1.8$ & $28.3 \pm 0.7$ & $20.0 \pm 0.4$ \\
\cline { 2 - 5 } & $30 \times 30$ & $80.4 \pm 1.9$ & $29.4 \pm 0.7$ & $22.4 \pm 0.5$ \\
\hline \multirow{3}{*}{ Malysh } & $2 \times 15$ & $65.7 \pm 1.1$ & $22.1 \pm 0.5$ & $24.4 \pm 0.5$ \\
\cline { 2 - 5 } & $15 \times 15$ & $68.3 \pm 1.2$ & $23.5 \pm 0.4$ & $25.5 \pm 0.5$ \\
\cline { 2 - 5 } & $30 \times 30$ & $70.7 \pm 1.4$ & $24.0 \pm 0.6$ & $27.2 \pm 0.5$ \\
\hline \multirow{3}{*}{ Ukraine-96 } & $2 \times 15$ & $86.3 \pm 1.0$ & $28.3 \pm 0.9$ & $32.0 \pm 0.7$ \\
\cline { 2 - 5 } & $15 \times 15$ & $91.6 \pm 1.2$ & $30.1 \pm 0.7$ & $34.0 \pm 0.7$ \\
\cline { 2 - 5 } & $30 \times 30$ & $99.3 \pm 1.2$ & $32.4 \pm 0.9$ & $35.3 \pm 0.8$ \\
\hline \multirow{3}{*}{ Myrnyi } & $2 \times 15$ & $67.2 \pm 0.7$ & $20.4 \pm 0.3$ & $21.2 \pm 0.3$ \\
\cline { 2 - 5 } & $15 \times 15$ & $71.3 \pm 0.7$ & $21.2 \pm 0.3$ & $22.6 \pm 0.3$ \\
\cline { 2 - 5 } & $30 \times 30$ & $73.5 \pm 0.7$ & $23.2 \pm 0.3$ & $24.0 \pm 0.3$ \\
\hline \multirow{3}{*}{ Krasnodarskyi-424 } & $2 \times 15$ & $85.6 \pm 0.9$ & $30.5 \pm 0.6$ & $28.4 \pm 0.5$ \\
\cline { 2 - 5 } & $15 \times 15$ & $92.2 \pm 1.0$ & $33.3 \pm 0.6$ & $30.3 \pm 0.6$ \\
\cline { 2 - 5 } & $30 \times 30$ & $97.6 \pm 1.2$ & $35.6 \pm 0.7$ & $32.3 \pm 0.6$ \\
\hline \multirow{3}{*}{ Don-883 } & $2 \times 15$ & $98.5 \pm 1.2$ & $32.2 \pm 0.7$ & $33.1 \pm 0.4$ \\
\cline { 2 - 5 } & $15 \times 15$ & $111.4 \pm 1.3$ & $34.0 \pm 0.8$ & $35.1 \pm 0.7$ \\
\cline { 2 - 5 } & $30 \times 30$ & $118.6 \pm 1.2$ & $35.4 \pm 0.9$ & $36.6 \pm 0.7$ \\
\hline
\end{tabular}

It is necessary to point out one important detail of the varietal, i.e. genotypical specificity in the formation of leaves. It was found out that in some varieties (Mutant-428 and Ukraine-96) a larger area is in the upper leaves, while in others (Malysh, Krasnodarskyiskyi-424), on the contrary, higher values of the leaf area are in the second layer. The varieties Myrnyi and Don-883 are characterized by their original feature: they have almost the same area of the first and the second layer leaves, but the reaction to the change of the area of nutrition is the same as in other varieties: in the thickened crops the area of leaves is the least and with an increase in the area of nutrition it increases respectively by the layers of leaves.

Analyses have shown that in early-ripening and middle-ripening varieties, the length of the $1^{\text {st }}$ from a panicle leaves is less than the length of the $2^{\text {nd }}$ leaves. The width of the same leaves, on the other hand, is greater than in the $1^{\text {st }}$ layer. In addition, the data of the Table 7 indicate that the difference between the varieties in the indices of dimensions of the top leaves (length, width, area) is small; we can only draw conclusions, that there is a tendency to higher values of width and area of the upper leaves in the middle-ripening 
varieties. The same tendency to some increase in the parameters in the middleripening genotypes exists in the $2^{\text {nd }}$ from the panicle leaves.

\section{Indices of plants tillering}

The term of "tillering of plants" has combined such signs as the total number of stems per plant, the number of productive and unproductive stems, as well as the number of buds per plant, which to a certain extent serve as an indicator of the potential of plants to tillering ${ }^{19}$.

Studies have shown that each variety at cultivation in equal conditions has permanent number of stems that is the named feature clearly defines the varietal specificity. Under normal conditions, buds of side shoots are set in the leaf sinuses regardless on varietal features, but grow and form side shoots only by those buds that are in the most favorable conditions ${ }^{20}$.

It is known that the number of side shoots increases under the increasing dose of nitrogen fertilizers, reducing plant density, lowering water temperature at the stage of tillering, changing water regime, etc. It is established that by changing the conditions of the environment at different stages of ontogenesis, it is possible to control the process of shoots formation, causing them to appear in different parts of the bush ${ }^{21}$.

There is a positive correlation between the productive tillering and yield. Instead, the maximum productivity varieties form not at the expense of a certain number of productive stems per plant, but as a result of the formation of the optimum number of stems per the unit of area. The highest yield, especially for highly thinned sprouts, will have the varieties with a greater potential ability to create side shoots ${ }^{22}$. In this regard, the study of potential ability to create side shoots in the promising varieties and rice samples is of a practical importance, especially for the northern areas of rice cultivation.

The main stem has the largest number of leaves and nodes. Under normal conditions, it is the most productive ${ }^{23}$. All shoots of the first, second and other orders are less productive. In this case, the performance decreases with increasing order and place of attaching the shoots on the mother plant.

In our experiments, increasing the nutrition area from $2 \times 15$ to $30 \times 30 \mathrm{~cm}$ led to an increase in the total number of shoots in 1.8-2.2 times

\footnotetext{
${ }^{19}$ Методика опытных работ по селекции, семеноводству, семеноведению и контроль за качеством риса. Краснодар, 1972. 155 с.

${ }^{20}$ Ерыгин П. С. Происхождение культурного риса. Физиологические основы орошения puса. Москва; Ленинград, 1950. С. 165-182.

${ }^{21}$ Саутич М.А. Формирование куста риса. Морфология растений. Москва, 1961. Т. 1. C. 124-127.

${ }^{22}$ Маджирова Л. Д., Куперман Ф. М. Основные этапы органогенеза у риса. Краткие итого научно-исследовательской работы за 1953-1954 г2. Краснодар, 1955. С. 69-72.

${ }^{23}$ Тур Н. С. Причины изреживания посевов от засоления и роль кущения в формировании стебля риса: автореф. дис. ... канд. биол. наук. Ростов-на-Дону, 1968. 20 с.
} 
(Table 7). It is discovered that the number of shoots of the $2^{\text {nd }}$ order has slightly changed in most varieties, and the biggest changes took place with the shoots of the $3^{\text {rd }}$ and $4^{\text {th }}$ orders. The studied varieties significantly differed by the total number of shoots and shoots of different order. The largest number of stems was formed by the varieties Antey and Ukraine-96. The first variety refers to the middle-late ripening group, and the second one - to the middleripening group.

Table 7

The number of shoots of different orders in the varieties at different areas of plants nutrition, pcs.

\begin{tabular}{|c|c|c|c|c|c|c|}
\hline \multirow{2}{*}{ Variety } & Nutrition & \multicolumn{6}{|c|}{ Order of the shoot } \\
\cline { 2 - 7 } & area, cm & $\mathbf{2}$ & $\mathbf{3}$ & $\mathbf{4}$ & $\mathbf{5}$ & $\mathbf{6}$ \\
\hline \multirow{3}{*}{ Mutant-428 } & $2 \times 15$ & 6.5 & 13.6 & 9.4 & 0.0 & 0.0 \\
\cline { 2 - 7 } & $15 \times 15$ & 7.0 & 18.1 & 22.3 & 0.0 & 0.0 \\
\cline { 2 - 7 } & $30 \times 30$ & 7.2 & 25.3 & 31.4 & 2.3 & 0.0 \\
\hline \multirow{3}{*}{ Malysh } & $2 \times 15$ & 6.1 & 11.3 & 13.4 & 0.0 & 0.0 \\
\cline { 2 - 7 } & $15 \times 15$ & 7.0 & 16.4 & 18.2 & 0.0 & 0.0 \\
\cline { 2 - 7 } & $30 \times 30$ & 7.5 & 25.8 & 29.3 & 0.0 & 0.0 \\
\hline \multirow{3}{*}{ Ukraine-96 } & $2 \times 15$ & 6.3 & 11.7 & 12.0 & 0.0 & 0.0 \\
\cline { 2 - 7 } & $15 \times 15$ & 7.6 & 15.3 & 19.5 & 3.3 & 0.0 \\
\cline { 2 - 7 } & $30 \times 30$ & 8.5 & 24.0 & 41.6 & 12.5 & 0.0 \\
\hline \multirow{3}{*}{ Krasnodarskyi-424 } & $2 \times 15$ & 6.0 & 9.7 & 12.4 & 0.0 & 0.0 \\
\cline { 2 - 7 } & $15 \times 15$ & 6.6 & 13.7 & 18.7 & 7.8 & 0.0 \\
\cline { 2 - 7 } & $30 \times 30$ & 7.2 & 19.5 & 26.0 & 6.3 & 2.2 \\
\hline \multirow{3}{*}{ Dnipro } & $2 \times 15$ & 5.3 & 8.9 & 13.0 & 0.0 & 0.0 \\
\cline { 2 - 7 } & $15 \times 15$ & 7.0 & 12.3 & 16.4 & 1.6 & 0.0 \\
\cline { 2 - 7 } & $30 \times 30$ & 7.8 & 19.0 & 28.4 & 8.5 & 0.0 \\
\hline \multirow{3}{*}{ Antey } & $2 \times 15$ & 6.4 & 13.1 & 14.0 & 1.3 & 0.0 \\
\cline { 2 - 7 } & $15 \times 15$ & 7.2 & 26.0 & 28.4 & 8.0 & 0.0 \\
\cline { 2 - 7 } & $30 \times 30$ & 8.1 & 29.1 & 32.6 & 9.2 & 2.2 \\
\hline
\end{tabular}

It was found out that even at the absence of fertilizers in thinned crops $(30 \times 30 \mathrm{~cm})$ there was formed a much larger total number and number of productive stems, than in the conditions of fertilization.

The varieties differ in nature of tillering under the influence of various doses of nitrogen fertilizers, but the differences between them were insignificant.

According to the Table 8 it is possible to conclude that in the reaction of the varieties there is only a tendency to increase the indicated number of stems: productive stems in the variety Ukraine-96 compared with Mutant-428.

Obviously, the differentiation of genotypes by the sensitivity to mineral nutrition, especially nitrogen, is manifested against the background of 
contrasting by the vegetative period varieties: the longer the vegetation period of the sample is, the greater the need for elements of root nutrition is, which is met by additional doses, and elevated doses of fertilizers contribute to the setting and development of additional shoots.

Table 8

Number of productive and unproductive stems of different orders in rice varieties under different cultivation conditions, pcs.

\begin{tabular}{|c|c|c|c|c|c|c|c|c|c|c|}
\hline \multirow{3}{*}{ 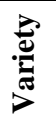 } & \multirow{3}{*}{$\begin{array}{l}\text { Power } \\
\text { area, } \\
\text { SM }\end{array}$} & \multirow{3}{*}{$\begin{array}{c}\text { Nitrogen } \\
\text { dose, } \\
\text { kg/ha }\end{array}$} & \multicolumn{8}{|c|}{ The order of the stems } \\
\hline & & & \multicolumn{2}{|c|}{2} & \multicolumn{2}{|c|}{3} & \multicolumn{2}{|c|}{4} & \multicolumn{2}{|c|}{5} \\
\hline & & & I & II & I & II & I & II & I & II \\
\hline \multirow{9}{*}{ 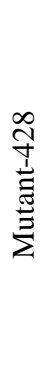 } & \multirow{3}{*}{$2 \times 15$} & 0 & 5.4 & 2.5 & 13.1 & 2.3 & 8.8 & 1.5 & 0.0 & 0.0 \\
\hline & & 90 & 6.0 & 4.1 & 16.4 & 3.6 & 9.5 & 1.7 & 0.6 & 0.0 \\
\hline & & 180 & 6.3 & 4.5 & 17.2 & 3.7 & 10.2 & 1.6 & 1.2 & 0.0 \\
\hline & \multirow{3}{*}{$15 \times 15$} & 0 & 6.8 & 3.7 & 18.3 & 3.5 & 22.5 & 0.6 & 0.0 & 0.0 \\
\hline & & 90 & 7.3 & 4.9 & 19.5 & 4.1 & 23.0 & 1.0 & 2.2 & 0.0 \\
\hline & & 180 & 7.6 & 5.0 & 20.1 & 5.3 & 25.2 & 0.9 & 2.6 & 0.5 \\
\hline & \multirow{3}{*}{$30 \times 30$} & 0 & 7.2 & 3.6 & 24.9 & 4.0 & 30.6 & 0.7 & 2.5 & 0.3 \\
\hline & & 90 & 7.8 & 4.6 & 25.1 & 4.5 & 31.3 & 1.1 & 3.1 & 1.0 \\
\hline & & 180 & 8.2 & 5.0 & 26.3 & 5.2 & 33.5 & 0.6 & 3.6 & 1.3 \\
\hline \multirow{9}{*}{ 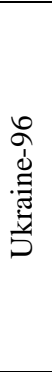 } & \multirow{3}{*}{$2 \times 15$} & 0 & 5.8 & 3.6 & 12.4 & 1.8 & 12.0 & 0.0 & 0.0 & 0.0 \\
\hline & & 90 & 6.1 & 4.0 & 14.3 & 2.4 & 12.8 & 0.0 & 0.3 & 0.0 \\
\hline & & 180 & 6.5 & 4.7 & 17.8 & 3.7 & 14.0 & 0.4 & 0.8 & 0.0 \\
\hline & \multirow{3}{*}{$15 \times 15$} & 0 & 7.2 & 3.6 & 16.1 & 2.2 & 20.6 & 1.0 & 3.5 & 0.9 \\
\hline & & 90 & 7.8 & 4.1 & 21.4 & 2.8 & 21.3 & 0.8 & 4.6 & 1.1 \\
\hline & & 180 & 8.3 & 4.5 & 23.5 & 3.0 & 23.4 & 0.7 & 5.0 & 0.5 \\
\hline & \multirow{3}{*}{$30 \times 30$} & 0 & 7.6 & 3.6 & 25.6 & 2.5 & 39.7 & 0.8 & 11.6 & 0.5 \\
\hline & & 90 & 8.1 & 3.9 & 26.3 & 2.8 & 40.5 & 0.9 & 12.4 & 0.6 \\
\hline & & 180 & 8.5 & 4.5 & 27.8 & 3.1 & 41.8 & 0.9 & 13.0 & 0.7 \\
\hline \multirow{2}{*}{$\stackrel{n}{n}$} & $\begin{array}{c}\text { by area of } \\
\text { nutrition }\end{array}$ & 0.04 & 0.05 & 0.08 & 2.12 & 0.03 & 0.92 & - & 0.01 & - \\
\hline & $\begin{array}{l}\text { by dose of } \\
\text { fertilizers }\end{array}$ & 0.03 & 0.05 & 0.07 & 1.96 & 0.03 & 0.87 & - & 0.01 & - \\
\hline
\end{tabular}

Note: I - The total number of shoots; II - The number of productive shoots of each order

The total number of shoots included all shoots that were formed. As a rule, at the ninth stage of organogenesis of the rice plant there can be observed shoots, which are at all stages of organogenesis, this is a biological specificity of rice. In the transition of the main panicle to the XI-XII stages of organogenesis, the correlation in the development of shoots changes significantly. Shoots, which are on V-VI stages, continue to develop and in 
favorable conditions reach the XII stage, that is mature; shoots that do not achieve until this time to the $\mathrm{V}$ stage, slow down their development and do not form after this stage, i.e. remain unproductive.

Moreover, a part of the fully formed stems under different unfavorable conditions (diseases, pests) does not realize its potential possibilities, that is, does not form kernels.

On the basis of the performed studies, we can conclude that side shoots of rice plants in the South of Ukraine are formed throughout the vegetation period, but the potential and real productivity is determined only by the shoots that begin to develop intensively at the early stages of organogenesis, reach to the onset of ripeness of the main panicle the V-VII stages of organogenesis, and the rest shoots stop their development until the maturation of the main one. Rice varieties differ in the proportion of the shoots of different orders, especially in the number of shoots of the 3-4 orders. The formation of lateral shoots is greatly affected by the nutrition area of plants than by the amount of nitrogen nutrition.

\section{Duration and intensity of flowering}

Flowering, pollination and fertilization occur at the IX stage of organogenesis. This is a very important period in ontogenesis of rice, because all the processes that occur at this stage have a direct relation to grain formation, and productivity of plants.

The duration, intensity, and character of rice flowering in various environmental conditions have been studied by many researchers. According to A. I. Siedlovsky and collaborators, in the Krasnodarskyi territory flowering of rice usually starts at 9-10 a.m. and ends at 14-16 o'clock. In the Primorsky Krai at the air temperature of $19-20^{\circ} \mathrm{C}$ rice begins to flower from $10-11$ hours in sunny weather and from 13-15 hours in cloudy. At the temperature of $23^{\circ} \mathrm{C}$ and higher flowering lasts from 8-10 hours to $16-17$ hours ${ }^{24}$.

According to our observations in the conditions of Skadovsky and Kalanchaksky districts of Kherson region flowering of rice in most cases starts from 10 o'clock in the morning and lasts up to 15-16 hours; in some days with high temperatures (above $20^{\circ} \mathrm{C}$ in the morning) flowering can be finished by 17 o'clock. The duration of flowering of different varieties of rice varies within 10-30 days, and the period of flowering of individual plants is 5-10 days. It depends on weather conditions and genetic features of a variety. The most intense rice flowering is on the $3^{\text {rd }}, 4^{\text {th }}$ and $5^{\text {th }}$ day. It is possible to conclude that the nature of rice flowring depends on the biology of variety and meteorological conditions of the environment ${ }^{25}$.

${ }^{24}$ Shibata M. progress in breeding cold - tolerant rice in Japan. Per. Rice Cold Tolerance Work Shop. Manila: IRRI, 1979. P. 21-124.

${ }_{25}$ Сметанин А. П. Создание сортов риса для северных районов отечественного рисосеяния: дис. ... д-ра биол. наук. Краснодар, 1975. 393 с. 
We have studied the peculiarities of flowering of different varieties of rice in the field researches at the Institute of Rice of NAAS (Skadovsk, Kherson region) and Kiliyska Research Station of Rice (Odesa region).

It is established that in the studied varieties that belong to different groups of ripeness, the duration of flowering is different (Table 9).

In the early-ripening varieties Mutant-428 and Malysh flowering lasts within 6-9 days, in the early variety Ukraine 96 and Mutant-428 - 7-10 days and in the late ripening ones Krasnodarskyi-424 and Don-883 - within 9-12 days. Data show that in the studied genotypes under different environmental conditions flowering of the plants lasts within the period of 6-12 days, with the influence of environmental conditions (conditions of the years/ geographical point of research) the duration of the flowering period may vary by 2-3 days.

The shortest period of flowering was in the early-ripening samples among the existing genetic collection (27 samples were investigated). It was found out that in this group of samples the genotypical differences on the flowering of panicles in different weather conditions is limited to 2-3 days (Table 10).

In the middle-ripening samples genotypical diversity by the duration of flowering is more essential and it is within 6-7 days. The biggest differences by the studied biological feature of rice were established between the lateripening samples, 9-10 days. Krasnodarskyi-424, Don-7115 belongs to the varieties with the shortest period of flowering; the genotypes of the longest flowering - Aromatica 834, MGR, AzROS / Corbetta. Rice varieties that are on the list of the State Register of Plant Varieties of Ukraine, the period of massive flowering lasts: Dniprovskyi - 6-8, Yantarnyi - 6-8, Agat - 6-8, Prestyzh - 7-9; Ukraine-96 - 9-11, Pamiati Hychkina - 9-12, Slavutych 9-11 days, respectively.

Table 9

The duration of flowering of rice varieties in different environmental conditions, days

\begin{tabular}{|c|c|c|c|c|c|c|}
\hline \multirow{2}{*}{ Variety } & \multicolumn{3}{|c|}{ Skadovsk, Kherson region } & \multicolumn{3}{c|}{ Kiliya, Odesa region } \\
\cline { 2 - 7 } & \multicolumn{3}{|c|}{ Years } & \multicolumn{3}{c|}{ Years } \\
\cline { 2 - 7 } & $\mathbf{2 0 0 2}$ & $\mathbf{2 0 0 3}$ & $\mathbf{2 0 0 4}$ & $\mathbf{2 0 0 2}$ & $\mathbf{2 0 0 3}$ & $\mathbf{2 0 0 4}$ \\
\hline Mutant-428 & 7 & 6 & 8 & 8 & 7 & 9 \\
\hline Malysh & 7 & 6 & 7 & 8 & 7 & 8 \\
\hline Ukraine 96 & 8 & 7 & 9 & 9 & 8 & 10 \\
\hline Myrnyi & 8 & 7 & 10 & 9 & 8 & 10 \\
\hline Krasnodarskyi-424 & 9 & 10 & 11 & 10 & 10 & 11 \\
\hline Don-883 & 9 & 11 & 12 & 10 & 10 & 12 \\
\hline
\end{tabular}


Table 10

The duration of flowering of rice samples of different ripening groups, days

\begin{tabular}{|c|c|c|c|c|c|}
\hline Group & Number of samples & \multicolumn{5}{|c|}{ Years } \\
\cline { 3 - 6 } of ripening & studied & $\mathbf{2 0 0 1}$ & $\mathbf{2 0 0 2}$ & $\mathbf{2 0 0 3}$ & $\mathbf{2 0 0 4}$ \\
\hline Early-ripening & 27 & $7-9$ & $6-9$ & $6-7$ & $8-11$ \\
\hline Middle-ripening & 56 & $8-15$ & $8-15$ & $7-13$ & $10-16$ \\
\hline Late ripening & 25 & $10-20$ & $9-18$ & $10-19$ & $11-21$ \\
\hline
\end{tabular}

\section{CONCLUSIONS}

1. The growth of rice stems depends on the biological characteristics of the varieties and plant nutrition area. In the South of Ukraine in some earlyripening varieties (Malysh) stem growth is stopped after flowering, but in most varieties (including early-ripening variety Mutant-428 and others) the growth of the stem continues until the end of the vegetation. An increase in the plant nutrition area leads to increased length and more significant accumulation of biomass in the plants until the end of vegetation.

2. The number of the formed leaves varies by the duration of the vegetation period: in the early-ripening varieties of rice - 9-10 leaves, middleripening ones - 11-12, late-ripening ones - 12-13 leaves. Late-ripening varieties form a much larger leaf surface than the genotypes of other groups of ripening. Under the increase in the plant nutrition area the total leaf surface area of the plants, including the area of the upper leaves, increases.

3. Side shoots of rice plants are formed throughout the vegetation period, but the potential and real productivity of plants is determined only by those shoots, which develop intensively at the early stages of organogenesis and reach to the beginning of the full ripeness of the main panicle to the V-VII stages of organogenesis. Flowering of rice plants in the early-ripening varieties takes place for 6-9 days, in the middle-ripening ones - 7-10 days and in the late-ripening ones - 9-12 days. The most intense flowering is attributed to the early-ripening varieties; the middle-ripening varieties have prolonged flowering period; and the least intensity and most prolonged flowering is in the late-ripening genotypes.

\section{SUMMARY}

The article contains the results of the researches on the dynamics of processes of growth and development of the plants depending on biological properties of varieties and cultivation conditions. The growth of rice stems depends on biological characteristics of varieties and plant nutrition area. In the South of Ukraine in some early-ripening varieties (Malysh) the stem growth is stopped after flowering, instead, most varieties (including earlyripening varieties Mutant-428 and others) are characterized with the continuous growth of stem to the end of the vegetation. Increase in the plant 
nutrition area leads to the increased length and more significant accumulation of biomass in the plants before the end of vegetation. The early-ripening varieties of rice form, mainly, 9-10 leaves, middle-ripening ones -11-12, lateripening - 12-13 leaves. Late-ripening varieties form a much larger leaf surface than the genotypes of other ripening groups. With the increase in the plant's nutrition area, the total area of the leaf surface of the plants, including the area of the upper leaves, increases. Lateral shoots in the rice plants are formed during the entire vegetation period, but the potential and real productivity of the plants is determined only by those shoots that develop intensively at the early stages of organogenesis and reach by the ripening of the main panicle to the V-VII stages of organogenesis. Flowering of rice plants in the early-ripening varieties lasts for 6-9 days, in the middle-ripening - 7-10 days and in the late ripening - 9-12 days, respectively. The most intense flowering is attributed to the early-ripening varieties; the middleripening varieties are characterized with prolonged flowering period and the least intensity and the longest time span of flowering is a feature of the lateripening genotypes.

\section{REFERENCES}

1. Ерыгин П. С. Физиология риса. Москва: Колос, 1981. 208 с.

2. Седловский А. И., Колточник С. Н., Колточник М. М. Формирование количественных признаков у риса. Алма-Ата, 1985. 214 с.

3. Методика державного сортовипробування сільськогосподарських культур. Київ, 2000. Вип. 1.100 с.

4. Сонде Т. А., Масливец В. А., Баргукова А. Я. Фотосинтетическая деятельность и урожайность сортов риса в зависимости от режима орошения и уровня азотного питания. Устойчивое производство риса: настоящее и перспективы: матер. Межд. науч.-практ. конф., 5-9 сентября 2006 г. Краснодар, 2006. С. 159-165.

5. Ванцовський А. А., Вожегов С. Г., Вожегова Р. А. Агроекологічні аспекти вирощування рису. Таврійський науковий вісник: зб. наук.пр. Херсон: Айлант, 2004. Вип. 32. С. 220-224.

6. Орлюк А. П., Вожегова Р. А., Федорчук М. І. Селекція і насінництво рису. Херсон: Айлант, 2004. 250 с.

7. Вожегова Р. А. Теоретичні основи і результати селекції рису в Україні: монографія. Херсон, 2010. 345 с.

8. Вожегова Р. А., Шпак Д. В., Петкевич 3. 3. Влияние погодных условий на реализацию потенциала продуктивности образцов национальной коллекции риса различных групп спелости. Материалы международной конференции. Скадовськ, 2008. С. 152-155.

9. Кольцов А. В. Технология возделывания риса в Крыму. Симферополь, 1991.415 с. 
10. Петкевич 3. 3., Шпак Т. Н., Вожегова Р. А. Влияние температурних условий на урожайность риса сортов разных групп спелости. Наукові праиі Південного філіалу «Кримський агротехнологічний університет» Національного аграрного ун-ту. Сімферополь, 2007. Вип. 100: Сільськогосподарські науки. С. 186-191.

11. Дуденко В. П., Байгулов П. Г., Устьянцева Р. Н. Удобрение риса на незасоленных такыровидных сероземах Акдалинского массива. Биология и минеральное питание риса. Алма-Ата, 1976. С. 184-200.

12. Мамедов Д. Х. Густота стояния как фактор повышения урожая риса при культуре пересадкой в Азербайджанской СССР: автореф. дис. ... канд. с.-х. наук. Баку, 1964. 23 с.

13. Волкова Н. П. К вопросу изучения агробиологических особенностей перспективных сортов риса. Mатериалы Всес. коорд.метод. совещания по селекиии, семеноводству и качеству риса, проектирования и эксплуатации рисовых оросительных систем. Краснодар, 1972. С. 37-39.

14. Бижанов И. Б. Сроки, способы и нормы высева риса в Талды-Курганской области: автореф. дис. ... канд. с.-х. наук. Алма-Ата, 1972. 23 c.

15. Зглинская Н. Л., Иванова А. В. Влияние калия на урожай риса в условиях различного содержания усвояемых форм его в почвах. Бюл. НТИ ВНИИ риса. Краснодар, 1972. Вып. VIII. С. 71-75.

16. Волкова Н. П., Сметанин А. П. Листообразование у некоторых сортов риса. Бюл. НТИ ВНИИ риса. Краснодар, 1973. Вып. IX. С. 10-14.

17. Дорошенко Т. Н., Петибская В. С. Особенности фотосинтеза и дыхания сортов риса интенсивного типа. Бюл. НТИ ВНИИ риса. 1980. Вып. 28. С. 38-42.

18. Алешин Е. П., Сметанин А. П. Минеральное питание риса. Краснодар: Краснодарское книжное издательство, 1965. 95 с.

19. Методика опытных работ по селекции, семеноводству, семеноведению и контроль за качеством риса. Краснодар, 1972. 155 с.

20. Ерыгин П. С. Происхождение культурного риса. Физиологические основы орошения риса. Москва; Ленинград, 1950. С. 165-182.

21. Саутич М.А. Формирование куста риса. Морфология растений. Москва, 1961. Т.1. С. 124-127.

22. Маджирова Л. Д., Куперман Ф. М. Основные этапы органогенеза у риса. Краткие итого научно-исследовательской работы за 1953-1954 г2. Краснодар, 1955. С. 69-72.

23. Тур Н. С. Причины изреживания посевов от засоления и роль кущения в формировании стебля риса: автореф. дис. ... канд. биол. наук. Ростов-на-Дону, 1968. 20 с. 
24. Shibata M. progress in breeding cold - tolerant rice in Japan. Per. Rice Cold Tolerance Work Shop. Manila: IRRI, 1979. P. 21-24.

25. Сметанин А. П. Создание сортов риса для северных районов отечественного рисосеяния: дис. ... д-ра биол. наук. Краснодар, $1975.393 \mathrm{c}$.

Information about the author: Vozhehova R. A.,

Doctor of Agricultural Sciences, Professor, Corresponding Member of NAAS, Institute of Irrigated Agriculture of National Academy of Agrarian Sciences of Ukraine

Kherson, Naddnipryanske, 73483, Ukraine 